\title{
Analisa Performansi Protokol TCP, UDP dan SCTP Pada Lalu Lintas Multimedia
}

\author{
Yesi Mardiana ${ }^{1}$, Julidian Sahputra ${ }^{2}$ \\ ${ }^{1}$ Program Studi Sistem Komputer, Universitas Dehasen Bengkulu \\ Email : yesi_mardiana@yahoo.com
}

\begin{abstract}
This study aims to analyze Performance of TCP, UDP and SCTP Protocol on Multimedia Traffic. The TCP (Transmission Control Protocol) protocol, UDP (User Datagram Protocol) and SCTP (Stream Control Transmission Protocol) reside on the same layer in the OSI-Layer at the Transport layer that controls the flow of data, data packets and so on. This research uses windows operating system and Softperfect Network Protocol Analyzer software. Where network analysis software has a complete feature such as can filter almost all the protocol on the OSI-Layer, has a report of easy to read results and so forth. From the test results conducted for three days by analyzing the online and offline way obtained SCTP protocol results both for Multimedia activities but can not be used simultaneously with other activities (such as video conversations). for everyday activities should use TCP and UDP protocol because it tends to be stable.
\end{abstract}

Keyword : TCP, UDP, SCTP

Intisari-Penelitian ini bertujuan untuk dapat melakukan Analisa Performansi Protokol TCP, UDP dan SCTP pada Lalu Lintas Multimedia. Protokol TCP (Transmission Control Protocol), UDP (User Datagram Protocol) dan SCTP (Stream Control Transmission Protocol) berada pada layer yang sama pada OSI-Layer yaitu pada layer Transport yang berfungsi untuk mengatur kendali aliran data, paket data dan lain sebagainya. Penelitian ini menggunakan sistem operasi windows dan software Softperfect Network Protocol Analyzer. Dimana software analisa jaringan ini memiliki fitur yang lengkap seperti bisa melakukan filter hamper semua protocol pada OSILayer, memiliki laporan hasil yang mudah dibaca dan lain sebagainya. Dari hasil pengujian yang dilakukan selama tiga hari dengan melakukan analisa cara online dan offline didapat hasil protocol SCTP baik untuk aktifitas Multimedia akan tetapi tidak bisa digunakan secara bersamaan dengan aktifitas yang lainnya (seperti percakapan video). untuk aktifitas seharihari sebaiknya menggunakan protocol TCP dan UDP karena cenderung stabil.

Kata Kunci : TCP, UDP, SCTP

\section{PENDAHULUAN}

Perkembangan teknologi multimedia berbasis video streaming dan voice saat ini semakin banyak digunakan sebagai aplikasi komunikasi pada internet. Pemanfaatan penggunaan teknologi tersebut juga sangat beragam dalam berbagai kegiatan sehingga pada data multimedia dibutuhkan suatu unjuk kerja protokol yang handal dan cepat dalam proses pengirimannya. TCP merupakan protokol yang $75 \%$ banyak digunakan untuk layanan internet saat ini. Namun pada protokol ini, ketika jaringan padat yang otomatis berdampak pada kongesti sangat tinggi menyebabkan time-out dan akan mengirimkan retransmisi karena sifatnya yang conection.

Hal ini akan menyebabkan delay yang tinggi dan berakibat turunnya throughput. Sedangkan UDP merupakan protokol yang ditujukan untuk kecepatan pengiriman data tanpa memperhatikan adanya kontrol konjesti dan koreksi kesalahan di dalam suatu jaringan. Namun akibat dari kecepatan pengiriman data yang tidak dapat dikendalikan, protokol UDP akan menggunakan seluruh bandwidth yang ada di dalam jaringan. Maka mulailah dikembangkan protokol baru yaitu SCTP. Ini adalah protokol yang reliable mirip dengan TCP, namun menyediakan fasilitas seperti multistreaming dan multi-homing untuk unjuk kerja 
yang lebih baik dan redundansi. Protokol SCTP ini diharapkan dapat menjembatani kelemahankelemahan yang dimiliki TCP dan UDP.

Tujuan dari penelitian ini adalah :

1. Mengetahui kinerja protokol TCP dalam melakukan proses atau lalu lintas multimedia

2. Mengetahui kinerja protokol UDP dalam melakukan proses atau lalu lintas multimedia

3. Mengetahui kinerja protokol SCTP dalam melakukan proses atau lalu lintas multimedia.

4. Menentukan protokol mana yang baik untuk lalu lintas multimedia yaitu berupa kelebihan dan kekurangan dari masing-masing protokol tersebut.

\section{TINJAUAN PUSTAKA}

\section{A. Jaringan Komputer}

Menurut Syafrizal (2005 : 2) jaringan komputer adalah "himpunan interkoneksi antara 2 komputer autonomous atau lebih yang terhubung dengan media transmisi kabel atau tanpa kabel (wireless)". Bila sebuah komputer dapat membuat komputer lainnya restart, shutdown, atau melakukan kontrol lainnya, maka komputer-komputer tersebut bukan autonomous. Dua unit komputer dikatakan terkoneksi apabila keduanya bisa saling bertukar data / informasi.

Sejarah jaringan komputer dimulai pada tahun 1940 di Amerika Serikat melalui proyek pengembangan komputer Model I di laboratorium Bell dan kelompok riset Harvard University yang dipimpin oleh Howard Aiken. Saat itu, proyek tersebut hanya bertujuan untuk memanfaatkan sebuah perangkat komputer sehingga dapat dipakai bersama. Pada tahun 1950, saat komputer mulai berkembang dan superkomputer lahir, muncullah kebutuhan akan sebuah komputer yang mampu melayani banyak terminal. Kemudian ditemukanlah konsep TSS (Time Sharing System) atau sistem antrian. Pada tahun 1969, terbentuklah jaringan komputer pertama yang disebut ARPANET.
Manfaat atau keuntungan dibangunnya jaringan komputer adalah:

1. Komputer-komputer yang saling terhubung dapat melakukan sharing file maupun sharing folder, yaitu pemakaian file atau direktori secara bersama-sama.

2. Dengan adanya penyimpanan file terpusat (file server), file atau data yang ada di server dapat saling dibagi.

3. Memungkinkan pemakaian aplikasi secara bersama-sama oleh multiuser.

4. Memudahkan kita membackup data (membuat data cadangan).

5. Memungkinkan kita untuk mendapatkan data terbaru/terkini secara cepat.

\section{B. Osi Layer Model}

OSI Reference Model for open networking atau model referensi jaringan terbuka OSI adalah sebuah model arsitektural jaringan yang dikembangkan oleh badan International Organization for Standardization (ISO) di Eropa pada tahun 1977 (Sofana, 2008). OSI sendiri merupakan singkatan dari Open System Interconnection.

Model ini disebut juga dengan "Model tujuh lapis OSI" (OSI seven layer model). Model OSI dibuat untuk mengatasi berbagai kendala internetworking akibat perbedaan arsitektur dan protocol jaringan. Dahulu, komunikasi antar komputer dari vendor yang berbeda sangat sulit dilakukan. Masing-masing vendor menggunakan protocol dan format data yang berbeda-beda. Sehingga International Organization for Standardization komunikasi (ISO) yang membuat dikenal sebagaisuatu Open arsitektur System Interconnection (OSI) model yang mendefinisikan standar untuk menghubungkan computer-komputer dari vendor yang berbeda. Layer pada model OSI ditunjukkan pada Tabel 1.

\section{Protokol TCP (Transmission Control Proto- col)}

Menurut Tanembaum (2003), di dalam penggunaan internet dan secara general jaringan TCP/ 
Tabel 1. Layer OSI

\begin{tabular}{|c|c|c|}
\hline Layer & Fungsi & Contoh Protokol \\
\hline Aplication & Menyediakan servis bagi berbagai aplikasi network & $\begin{array}{l}\text { NNTP, H7, Modbus, SIP, SSI, DHCP, } \\
\text { FTP, Gopher, HTTP, NFS, NTP. RTP, } \\
\text { SMPP, SMTP, Telnet }\end{array}$ \\
\hline Presentation & $\begin{array}{l}\text { Mengatur konversi dan translasi berbagai format data, } \\
\text { seperti kompresi data dan enkripsi data }\end{array}$ & $\begin{array}{l}\text { TDI, ASCII, EBCDIC, MIDI, MPEG, } \\
\text { ASCII7 }\end{array}$ \\
\hline Session & $\begin{array}{l}\text { Mengatur sesi (session) yang meliputi estabilishing } \\
\text { (memulai sesi), maintaining (mempertahankan sesi) } \\
\text { dan terminating (mengakhiri sesi) antar entitas yang } \\
\text { dimiliki oleh presentation layer }\end{array}$ & $\begin{array}{l}\text { SQL, X Windows, DNS, NetBIOS, } \\
\text { ASP, SCP, OS Scheduling, RPC, NFS, } \\
\text { ZIP }\end{array}$ \\
\hline Transport & $\begin{array}{l}\text { Menyediakan end to end communication protocol. } \\
\text { Layer ini bertanggung jawab terhadap "keselamatan } \\
\text { data" seperti mengatur flow control (kendali aliran } \\
\text { data), error detection (deteksi error) dan correction } \\
\text { (koreksi), data secuencing (urutan data) dan size of } \\
\text { the packet (ukuran data) }\end{array}$ & TCP, SPX, UDP, SCTP, IPX \\
\hline Network & $\begin{array}{l}\text { Menentukan rute yang dilalui oleh data. Layer ini } \\
\text { menyediakan logical addressing (pengalamatan } \\
\text { logika) dan path determination (penentuan rute tujuan) }\end{array}$ & $\begin{array}{l}\text { IP, ICMP, IPSec, ARP. RIP, IGRP, BGP, } \\
\text { QSPF, NBF, Q.931 }\end{array}$ \\
\hline Data Link & $\begin{array}{l}\text { Menentukan pengalamatan fisik (hardware address), } \\
\text { error notifikasi (pendeteksi error), frame flow control } \\
\text { (kendali aliran frame) dan topologi aliran network } \\
\text { Ada dua sub layer pada data link, yaitu Logical Link } \\
\text { Control (LLC) dan Media Access Control (MAC) } \\
\text { LLC mengatur komunikasi, seperti error notification } \\
\text { dan flow control. } \\
\text { Sedangkan MAC mengatur pengalamatan fisik yang } \\
\text { digunakan dalam proses komunikasi antar adapter }\end{array}$ & $\begin{array}{l}802.3 \text { (Ethernet) } \\
802.11 \mathrm{a} / \mathrm{b} / \mathrm{g} / \mathrm{n} \\
\text { MAC/LLC, } 802.1 \mathrm{Q} \\
\text { (VLAN), ATM, CDP, HDP, FDDI, Fibre } \\
\text { Channel Frame Relay, } \\
\text { SDLC, HDLC, ISL, PPP } \\
\text { Q.921, Token Ring }\end{array}$ \\
\hline Physical & $\begin{array}{l}\text { Layer ini menentukan masalah kelistrikan / } \\
\text { gelombang / medan dan berbagai prosedur / fungsi } \\
\text { yang berkaitan dengan link fisik, seperti besar } \\
\text { tegangan / arus listrik, panjang maksimal media } \\
\text { transmisi, pergantian fasa, jenis kabel dan konektor }\end{array}$ & $\begin{array}{l}\text { RS.232, V.35, V.34, L430, L.431, T1, } \\
\text { E1, 10BASE-T, 100BASE-TX, POTS, } \\
\text { SONET, DSL, 802.11a/b/g/n PHY, Hub, } \\
\text { Repeater, Fibre, Optics }\end{array}$ \\
\hline
\end{tabular}

IP, pengomunikasian setiap aplikasi dengan menggunakan protokol pendukung. Protokol ini bagian di dalam layer transport (transport layer) pada standar OSI yaitu bagian yang memberikan efisiensi dan jaminan komunikasi end-to-end.

Layer transport ini terdapat 2 protokol utama yaitu protokol UDP (User Datagram Protocol) dan protokol TCP (Transmission Control Protokol). Protokol ini untuk mendukung konsep jaringan berbasis IP. Telah diketahui bahwa IP (internet protocol) sebagai protokol jaringan internet yang mengkomunikasikan dua titik jaringan serta secara spesifik semua aplikasi dan layanan terpengaruh port tetapi kondisi konsep jaringan IP tidak memberikan jaminan. Jaminan tersebut adalah jaminan bahwa data akan tersampaikan pada destination yang benar dan data tersampaikan de- ngan benar (Kurose dan Ross, 2000, section 1.3). Model layanan IP merupakan best effort bagi tercapainya data antara komunikasi dua titik jaringan. TCP dan UDP ini mendukung hingga 65536 virtual port dan ini digunakan oleh semua aplikasi dalam melakukan komunikasi pertukaran data.

TCP adalah protokol yang dapat dipercaya dan dirancang untuk menyediakan alur data pada jaringan internet yang secara umum diketahui dengan kondisi tidak dapat dipercaya serta dirancang untuk beradaptasi dengan peralatan jaringan terhadap berbagai macam permasalahannya. Dirancangnya protokol ini untuk dapat dipercaya maka TCP bersifat connection oriented dalam mengirimkan data. TCP menjamin data yang terpercaya dengan menggunakan ARQ (Automatic Repeat Request). ARQ akan mentransmisikan 
secara otomatis berdasarkan informasi gagal diterimanya data ACK (Acknoledgement) dari penerima data. Untuk menjamin kontrol efektif terhadap hambatan maka dilakukan dengan cara mengestimasi delay dari transmisi round trip time secara akurat, sehingga dengan mempergunakan informasi balasan dari jaringan tersebut maka dapat mendeteksi sebuah kemacetan jaringan dan menyelesaikannya. Penjelasan TCP dapat ditemui pada RFC 793, 1122 dan 1323.

TCP memiliki tujuh fitur utama yaitu sebagai berikut:

1. Connection oriented, aplikasi meminta koneksi dan menggunakannya dalam transfer data.

2. Point-to-point communication, setiap koneksi TCP memiliki pasti dua titik.

3. Reliability, TCP menjamin bagi data yang dikirimkan dalam koneksi dapat terkirim dengan pasti tanpa ada yang hilang atau dobel.

4. Full-duplex connection, koneksi TCP memperbolehkan data untuk berkoneksi dari salah satu titik koneksi setiap saat.

5. Stream interface, TCP memperbolehkan aplikasi untuk mengirimkan koneksi yang berkesinambungan.

6. Reliable startup, membutuhkan persetujuan dari kedua aplikasi untuk melakukan koneksi baru.

7. Graceful shutdown, aplikasi dapat membuka aplikasi, mengirim data dan menutup koneksi serta menjamin bahwa data sampai sebelum koneksi terputus.

\section{Protokol UDP (User Datagram Protocol)}

Pada section ini dijelaskan tentang protokol UDP. Memperkuat pernyataan Tenembaum (2003), pada bagian lain blog ini yaitu protokol TCP bahwa layer transport terdapat 2 protokol utama yaitu protokol UDP (User Datagram Protocol) dan protokol TCP (Transmission Control Protokol). Protokol ini untuk mendukung konsep jaringan berbasis IP. Telah diketahui bahwa IP (internet protocol) sebagai protokol jaringan internet yang mengkomunikasikan dua titik jaringan serta secara spesifik semua aplikasi dan layanan terpengaruh port tetapi kondisi konsep jaringan IP tidak memberikan jaminan. Jaminan tersebut adalah jaminan bahwa data akan tersampaikan pada destination yang benar dan data tersampaikan dengan benar.

Berbeda dengan TCP, protokol UDP adalah protokol yang bersifat connectionless dalam mentransmisi data dan tidak mengenal dalam pengecekan terhadap error pengiriman data.

Protokol UDP pada dasarnya hanya mengandung IP dengan tambahan header singkat. Protokol UDP tidak melakukan sebuah proses kontrol alur data, kontrol kesalahan ataupun pengiriman ulang terhadap kesalahan sehingga hanya menyediakan interface ke protokol IP. UDP sangat berguna sekali pada situasi client-server dan penjelasan UDP lebih detil dapat ditemui pada RFC 768.

UDP memiliki karaketeristik yaitu sebagai berikut:

1. End-to-end, UDP dapat mengidentifikasi proses yang berjalan dalam komputer.

2. Connectionless, UDP memiliki paradigma Connectionless tanpa membuat koneksi sebelumnya dengan tanpa adanya control.

3. Message-oriented, mengirimkan dan menerima data secara segmen.

4. Best-effort, yang utama adalah pengiriman yang terbaik.

5. Arbitrary interaction, UDP dapat menerima dan mengirim dari banyak proses.

6. Operating system independent, berdiri sendiri dalam operating system.

\section{E. Protokol SCTP (Stream Control Transmissi- on Protokol)}

Stream Control Transmission Protokol (SCTP) adalah unicast protokol dan mendukung pertukaran data antara dua sisi secara tepat, meskipun hal ini mungkin dapat diwakilkan dengan banyak IP address. Transmisi pada SCTP adalah full duplex dan memberikan transmisi yang reliable, 
mampu mendeteksi data hilang, tidak terurut, mengganda (duplikat), atau rusak.

SCTP dapat dicirikan sebagai pesan-berorientasi, yang berarti mengangkut urutan pesan (masing-masing menjadi kelompok bytes), SCTP pengirim mengirimkan pesan dalam satu operasi, dan bahwa pesan yang tepat akan diteruskan ke proses aplikasi penerima dalam satu operasi.

\section{F. Multimedia}

Menurut Suyanto (2004:18) multimedia secara umum adalah penggabungan berbagai infomasi dengan menggunakan fasilitas dari komputer. Multimedia yang berasal dari kata multi yang berarti banyak atau lebih dari satu dan media yang dapat diartikan penyajian suatu tempat. Multimedia adalah pemanfaatan komputer untuk membuat dan menggabungkan teks, audio, gambar, bergerak (video dan animasi dengan menggunakan link dan tool yang memungkinkan pemakaian melakukan navigasi, berinteraksi, berkreasi dan berkomunikasi.

Kelebihan multimedia adalah menarik indera dan minat, karena merupakan gabungan antara pandangan, suara dan gerakan. Lembaga Riset dan Penerbitan Komputer yaitu Computer Technology Research (CTR), menyatakan bahwa orang hanya mampu mengingat $20 \%$ dari yang dilihat dan 30\% dari yang didengar. Tetapi orang dapat mengingat $50 \%$ dari yang dilihat dan didengar dan 30\% dari yang dilihat, didengar dan dilakukan sekaligus. Maka multimedia sangatlah efektif. Multimedia menjadi tool yang ampuh untuk pengajaran dan pendidikan serta untuk meraih keunggulan bersaing perusahaan.

\section{G. Software SoftPerfect Network Protocol Analyzer}

Menurut Dhida (2003:1) SoftPerfect Network Protocol Analyzer adalah alat profesional gratis untuk menganalisis, debugging, pemeliharaan dan pemantauan jaringan lokal dan koneksi internet. Ia menangkap data melewati koneksi dial-up atau kartu jaringan Ethernet, menganalisis data ini dan kemudian mewakili dalam bentuk yang mudah dibaca. SoftPerfect Network Protocol Analyzer adalah alat yang berguna bagi administrator jaringan, spesialis keamanan, pengembang aplikasi jaringan dan siapa pun yang membutuhkan gambaran yang komprehensif tentang lalu lintas yang melewati koneksi jaringan atau segmen jaringan area lokal.

SoftPerfect Network Protocol Analyzer fitur decoding penuh dari protokol tingkat rendah berikut: AH, ARP, ESP, ICMP, ICMPv6, IGMP, IP, IPv6, IPX, LLC, MSG, REVARP, RIP, SAP, SER, SNAP, SPX, TCP dan UDP. Hal ini juga melakukan rekonstruksi penuh tingkat atas protokol seperti HTTP, SMTP, POP, IMAP, FTP, TELNET dan lain-lain.

Adapun fitur utama SoftPerfect Network Protocol Analyzer

1. Mampu menangkap semua paket jaringan.

2. Menkonversi paket dan menampilkannya dalam format yang mudah dibaca.

3. Memungkinkan Anda membangun kustom paket dan mengirim mereka ke jaringan.

4. Menawarkan sistem lalu lintas yang fleksibel dalam penyaringan. Filter apapun dapat menjadi inklusif atau eksklusif.

5. Merekonstruksi paket ke jaringan sehingga Anda dapat dengan mudah melihat pertukaran data lengkap Telnet, POP3, SMTP, IMAP, FTP, HTTP dan protokol lainnya.

6. Memungkinkan Anda memonitor koneksi loopback dalam sistem.

\section{METODOLOGI PENELITIAN}

\section{A. Subjek Penelitian}

Tempat penelitian dilaksanakan pada warung internet Roemah Browsing yang beralamt di Jl. Meranti No. 15 Sawah Lebar. Warung internet Roemah Browsing berdiri pada tahun 2008, yang didirikan oleh Bapak Asikin. Dimana pada tahun ini warnet Roemah Browsing sudah memasuki tahun ke 7. 
Warung internet Roemah Browsing mengutamakan kenyamanan dan kecepatan dalam melakukan browsing, kirim-kirim email, lihat video klip di youtube dan aktifitas lainnya.

\section{B. Metodologi Penelitian}

Dalam Penelitian ini penulis menggunakan metode penelitian kuantitatif eksperimen. Metode ini bersifat validation atau menguji, yaitu menguji pengaruh satu atau lebih variabel terhadap variabel lain.

\section{Perangkat Keras dan Perangkat Lunak 1) Perangkat Keras}

Adapun instrumen perangkat keras yang digunakan dalam penelitian ini adalah Personal Komputer dengan spesifikasi sebagai berikut :

1. Laptop Core i3 dan pc client pada Warnet Roemah Browsing

2. Memory $4 \mathrm{~GB}$

3. HDD $320 \mathrm{~GB}$

4. Monitor 18 "

5. Keyboard + Mouse

\section{2) Perangkat Lunak}

Perangkat lunak yang penulis gunakan dalam penelitian ini adalah :

1. Sistem Operasi Windows 7

2. SoftPerfect Network Protocol Analyzer

\section{Metode Pengumpulan Data}

Adapun metode penelitian yang digunakan penulis adalah :

1. Metode eksperimen terhadap protokolprotokol TCP, UDP dan SCTP untuk proses atau lalu lintas multimedia.

2. Metode wawancara yaitu melakukan proses tanya jawab yang dilakukan secara langsung pada Bapak Adi selaku manager di warung internet roemah browsing.

3. Studi Pustaka adalah suatu metode pengumpulan data yang diambil dari perpustakaan atau instansi yang berupa karya ilmiah, jurnal, buku-buku serta dari internet yang berhubungan dengan penulisan ini. Tujuan dari studi pustaka ini adalah untuk mendalami dan memperoleh keterangan yang lengkap terhadap obyek yang diteliti.

\section{E. Perancangan Sistem}

Diagram blok global dari dari jaringan warung internet Roemah Browsing adalah sebagai berikut.

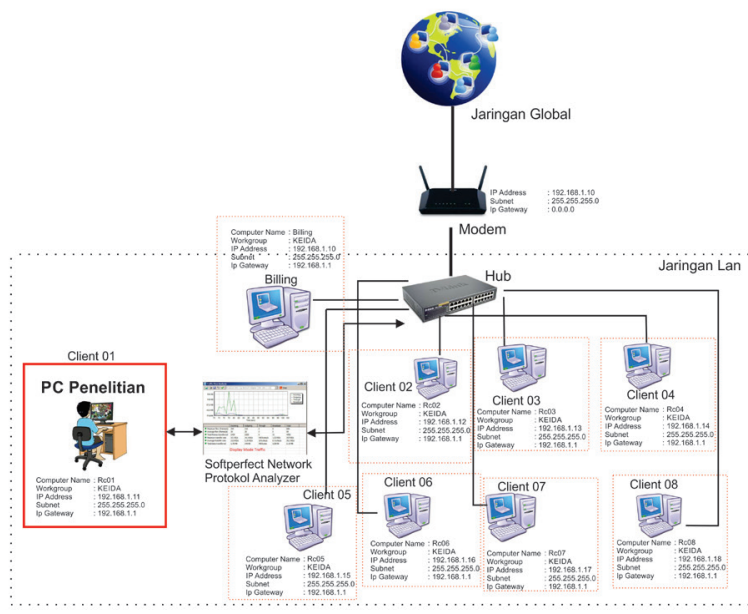

Gambar 1. Blok Diagram Global

\section{Keterangan Gambar}

1. Warung internet Roemah Browsing memiliki 9 PC yang mana 1 PC untuk Billing dan 8 PC untuk klien, memiliki 1 buah Hub dan 1 buah modem

2. Semua PC saling terhubung menjadi sebuah jaringan lan.

3. Konfigurasi settingan ip pada jaringan lan Roemah Browsing adalah :

\begin{tabular}{|c|c|c|}
\hline \multirow[t]{3}{*}{ Modem } & : IP Address & : 192.168 .1 .1 \\
\hline & Subnet & 255.255 .255 .0 \\
\hline & Gateway & 0.0 .0 .0 \\
\hline \multirow[t]{5}{*}{ Biling } & : Computer Name & Billing \\
\hline & Workgroup & KEIDA \\
\hline & IP Address & 192.168.1.10 \\
\hline & Subnet & 255.255 .255 .0 \\
\hline & Gateway & 192.168.1.1 \\
\hline \multirow[t]{4}{*}{ Client 01} & : Computer Name & $\mathrm{PC} 01$ \\
\hline & Workgroup & KEIDA \\
\hline & IP Address & 192.168.1.11 \\
\hline & Subnet & 255.255 .255 .0 \\
\hline
\end{tabular}


Gateway $\quad: 192.168 .1 .1$

Client 02 : Computer Name : PC02

$\begin{array}{lll}\text { Workgroup } & : \text { KEIDA } \\ \text { IP Address } & : & 192.168 .1 .12 \\ \text { Subnet } & : & 255.255 .255 .0 \\ \text { Gateway } & : & 192.168 .1 .1\end{array}$

Dan seterusnya sampai client 08 . Yang menjadi perbedaan adalah IP address dan computer name Client 08 : Computer Name : PC08

$\begin{array}{ll}\text { Workgroup } & : \text { KEIDA } \\ \text { IP Address } & : 192.16 .1 .18 \\ \text { Subnet } & : 255.255 .255 .0 \\ \text { Gateway } & : 192168.11\end{array}$

\section{HASIL DAN PEMBAHASAN}

\section{A. Pengujian Protokol TCP}

Untuk pengujian ini penulis melakukan pemutaran video dari internet dengan alamat : https://www.youtube.com/watch? $\mathrm{v}=\mathrm{PDW} 1 \mathrm{jmC}$ laz8\&index $=4 \&$ list $=$ RDyLeQAS5xSAg

Untuk pengujian protokol TCP terlebih dahulu penulis mengatus settingan pada protocol, yaitu dengan hanya memilih satu filter protocol TCP yang penulis centang. Seperti pada Gambar 2.

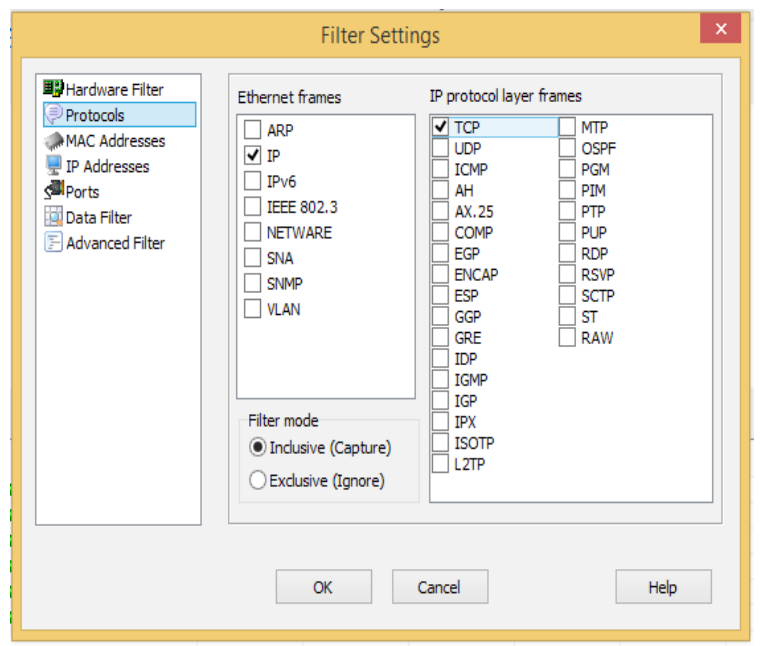

Gambar 2. Tampilan Filter Setting Protocol TCP

Selanjutnya penulis lakukan capture atau perekaman data. Seperti menghasilkan data seperti pada Gambar 3.
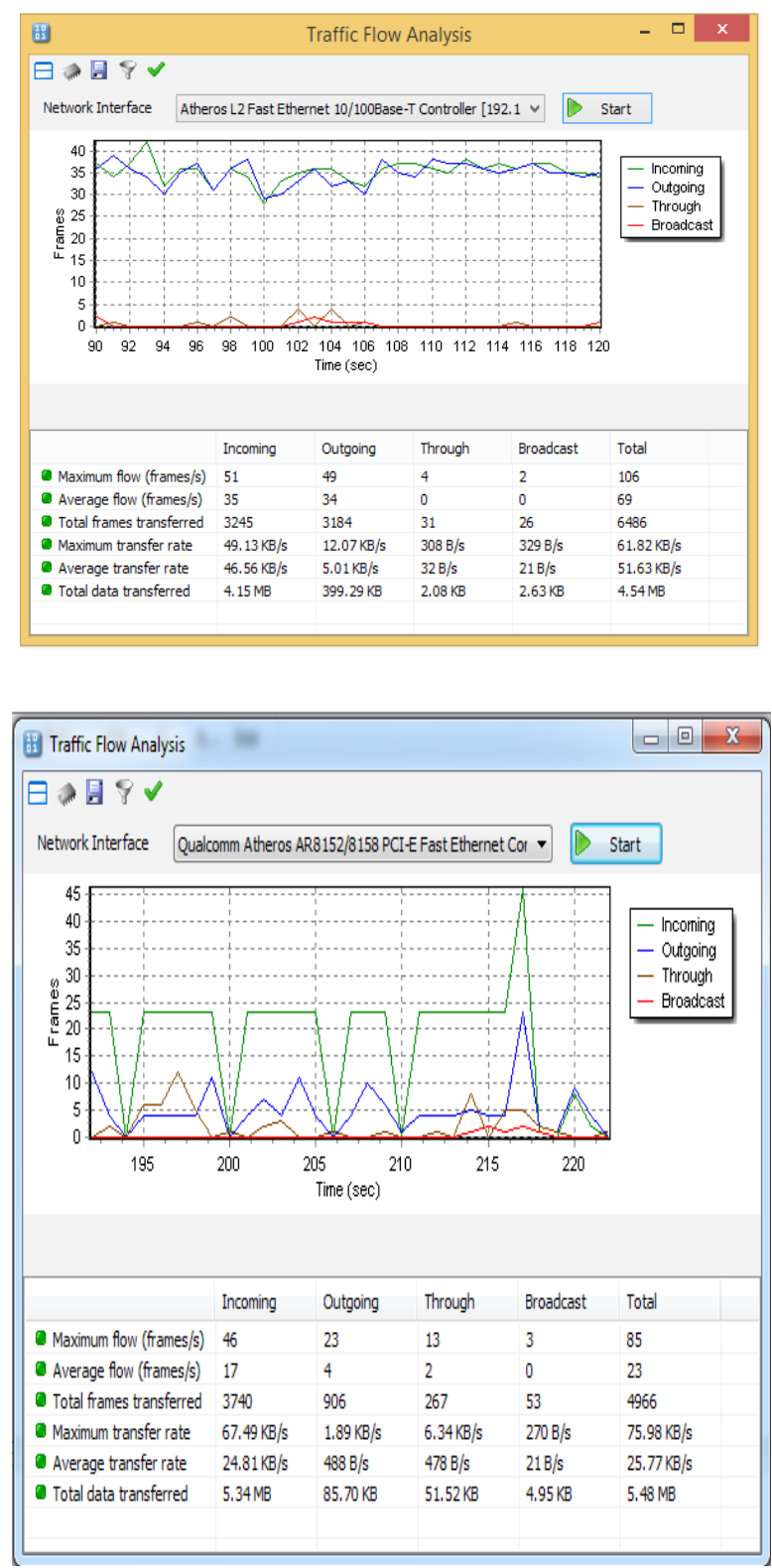

Gambar 3. Tampilan Data Hasil Protocol TCP

Dari gambar 3 dapat dilihat bahwa waktu pengambilan data selama 120 detik dan 220 detik. Total data transper selama 120 detik adalah 4.54 MB dan 225 detik adalah 5.48 MB. Total frame yang ditransfer adalah total frame yang diterima oleh komputer atau pc kita dari media youtube sebanyak 6486. Maximum Troughput adalah 308 $\mathrm{B} / \mathrm{s}$ yang menandakan kemampuan maximum protocol TCP pada penelitian ini adalah $308 \mathrm{~B} / \mathrm{s}$.

\section{B. Pengujian Protokol UDP}

Untuk pengujian pada tahap ini penulis melakukan pemutaran video dari internet dengan 
alamat yang sama dengan protocol TCP. Untuk pengujian protocol UDP terlebih dahulu penulis mengatus settingan pada protocol, yaitu dengan hanya memilih satu filter protocol UDP yang penulis centang. Seperti pada gambar 4 .

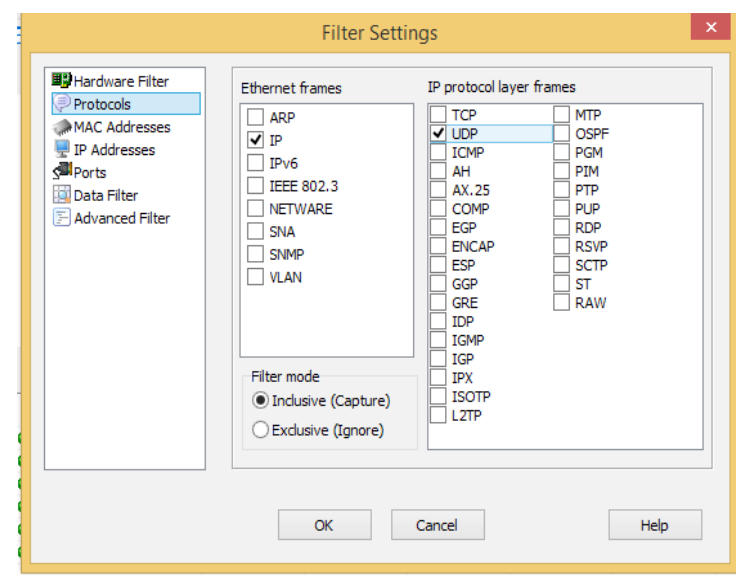

Gambar 4. Tampilan Filter Setting Protocol UDP

Selanjutnya penulis lakukan capture atau perekaman data. Seperti menghasilkan data seperti pada Gambar 5.

Dari Gambar 5 dapat dilihat bahwa waktu pengambilan data selama 120 detik dan 224 detik, total data transper selama 120 detik adalah 4.48 MB dan 224 adalah 5.58 MB, total frame yang ditransper adalah total frame yang diterima oleh komputer atau pc kita dari media youtube sebanyak 6547, dan maximum Troughput adalah 308 $\mathrm{B} / \mathrm{s}$ dan $1.59 \mathrm{~KB} / \mathrm{s}$ yang menandakan kemampuan maximum protocol UDP pada penelitian ini adalah $308 \mathrm{~B} / \mathrm{s}$ dan $1.59 \mathrm{~KB} / \mathrm{s}$.

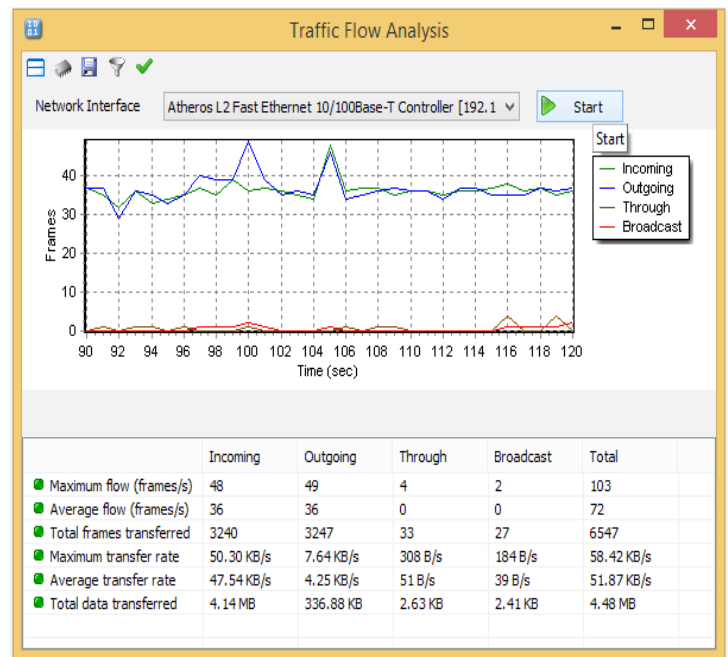

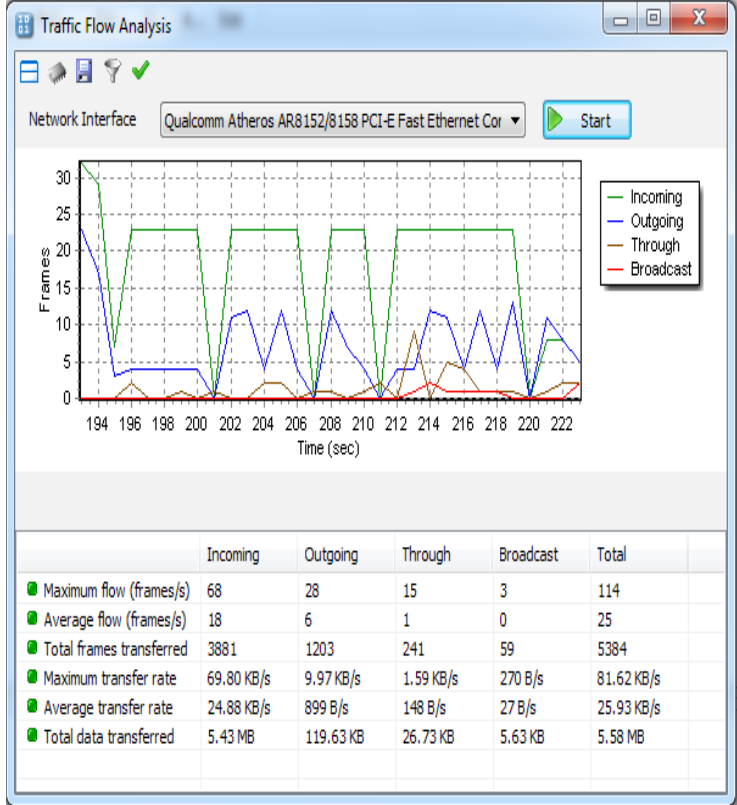

Gambar 5. Tampilan Data Hasil Protocol UDP

\section{Pengujian Protokol SCTP}

Untuk pengujian pada tahap ini penulis melakukan pemutaran video dari internet dengan alamat yang sama dengan protocol TCP dan UDP. Untuk pengujian protokol SCTP terlebih dahulu penulis mengatus settingan pada protocol, yaitu dengan hanya memilih satu filter protocol SCTP yang penulis centang. Seperti pada Gambar 6.

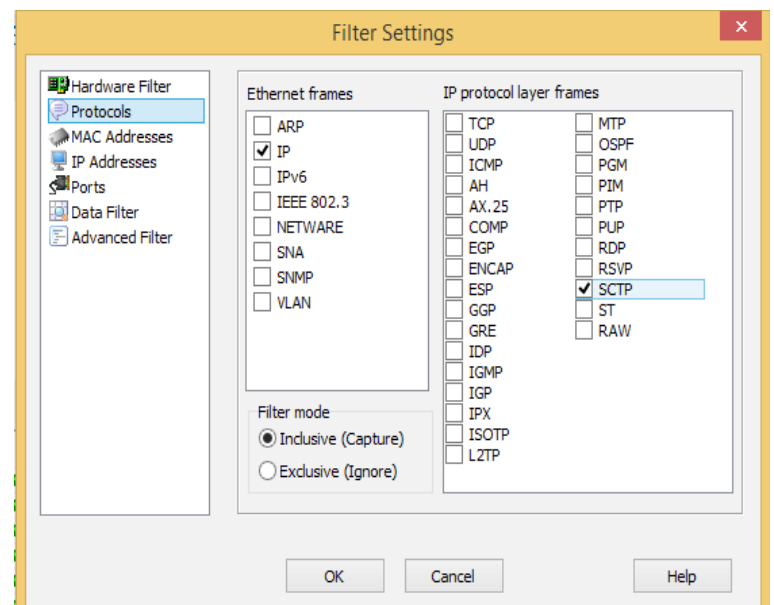

Gambar 6. Tampilan Filter Setting Prtocol SCTP

Selanjutnya penulis lakukan capture atau perekaman data. Seperti menghasilkan data seperti pada Gambar 7. 

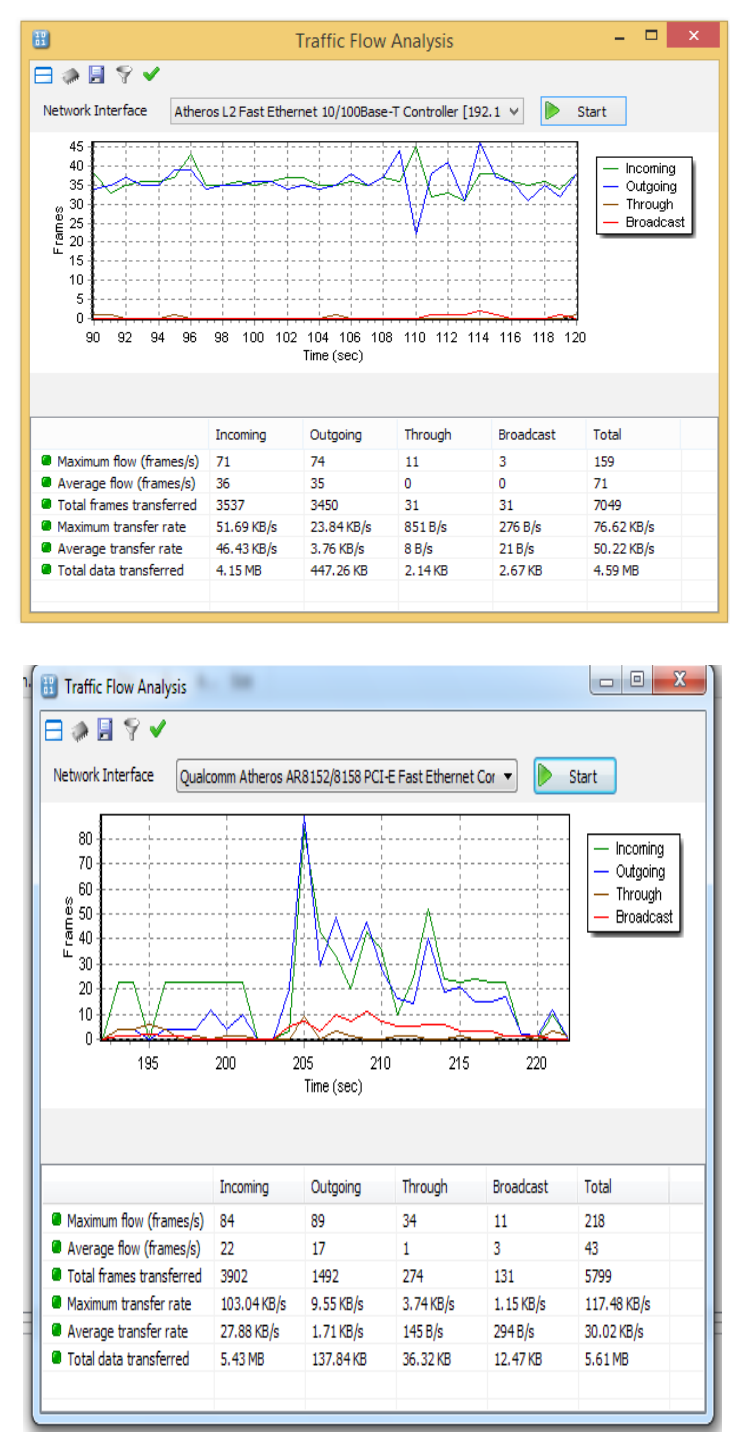

Gambar 7. Tampilan Data Hasil Protocol SCTP

Dari gambar 7 dapat dilihat bahwa waktu pengambilan data selama 120 detik dan 225 detik, total data transper selama 120 detik adalah 4.59 MBdan 225 detik adalah 5.61, total frame yang ditransper adalah total frame yang diterima oleh komputer atau pc kita dari media youtube sebanyak 7049, dan maximum Troughput adalah 851 $\mathrm{B} / \mathrm{s}$ dan $3.74 \mathrm{~KB} / \mathrm{s}$ yang menandakan kemampuan maximum protocol SCTP pada penelitian ini adalah $851 \mathrm{~B} / \mathrm{s}$ dan $3.74 \mathrm{~KB} / \mathrm{s}$.

\section{Hasil}

Dari hasil pengujian dan analisa yang penulis lakukan ditemukanlah protocol yang bagus untuk melakukan aktivitas multimedia seperti menonton video online, video streaming, konfrensi vi- deo dan lain sebagainya.

Penulis melakukan pengujian pada penelitian ini yaitu pada media online, yaitu pada:

1. https://www.youtube.com/watch?v=PDW1jmClaz8\&index $=4 \&$ list $=$ RDyLeQAS5xSAg

2. Sharing data video dari client dengan kapasitas file $5.409 \mathrm{~KB}$

Adapun dari pengujian yang penulis lakukan maka penulis mendapatkan hasil pengujian seperti dapat dilihat pada Tabel 2.

Berdasarkan Tabel 2, dapat diketahi hal-hal sebagai berikut.

Maximum Flow merupakan kemampuan masing-masing protocol untuk melakukan komunikasi multimedia yang mana semakin besar menandakan semakin baik. Adapun maksimum flow masing-masing protocol adalah :

1. TCP : 106 Frame/s

2. UDP : 103 Frame/s

3. SCTP : 159 Frame/s

Average Flow adalah rata-rata media (protocol) untuk melakukan transper

Total Frames Transper adalah total frame yang berhasil ditransper selama 120 detik (waktu yang penulis gunakan pada penelitian ini). Semakin besar frame yang diterima (ditransper oleh media atau protokol) berarti akan menghasil video yang bagus (tidak putus-putus atau sedikit putusputus). Adapun hasil untuk masing-masing protocol adalah :
1. TCP : 6487
2. UDP : 6574
3. SCTP : 7049

Average transfer merupakan waktu rata-rata yang digunakan.

Total data tranpers adalah data yang berhasil ditransper atau diterima oleh protocol. Yang mana hasilnya adalah :
1. TCP : $4.54 \mathrm{MB}$
2. UDP : $4.48 \mathrm{MB}$
3. SCTP : $4.59 \mathrm{MB}$

Ringkasan hasil pengujian setiap protokol disajikan pada Tabel 3, Tabel 4, dan Tabel 5. 
Tabel 2. Hasil Pengujian dari Youtube

\begin{tabular}{|c|c|c|c|c|c|}
\hline \multicolumn{6}{|c|}{ TCP } \\
\hline & Incoming & Outgoing & Through & Broadcast & Total \\
\hline Maximum flow (frames/s) & 51 & 49 & 4 & 2 & 106 \\
\hline Average flow (frames/s) & 35 & 34 & 0 & 0 & 69 \\
\hline Total frames transferred & 3245 & 3184 & 31 & 26 & 6486 \\
\hline Maximum transfer rate & $49.13 \mathrm{~KB} / \mathrm{s}$ & $12.07 \mathrm{~KB} / \mathrm{s}$ & $308 \mathrm{~B} / \mathrm{s}$ & $329 \mathrm{~B} / \mathrm{s}$ & $61.82 \mathrm{~KB} / \mathrm{s}$ \\
\hline Average transfer rate & $46.56 \mathrm{~KB} / \mathrm{s}$ & $5.01 \mathrm{~KB} / \mathrm{s}$ & $32 \mathrm{~B} / \mathrm{s}$ & $21 \mathrm{~B} / \mathrm{s}$ & $51.63 \mathrm{~KB} / \mathrm{s}$ \\
\hline Total data transferred & $4.15 \mathrm{MB}$ & $399.29 \mathrm{~KB}$ & $2.08 \mathrm{~KB}$ & $2.63 \mathrm{~KB}$ & $4.54 \mathrm{MB}$ \\
\hline \multicolumn{6}{|c|}{ UDP } \\
\hline & Incoming & Outgoing & Through & Broadcast & Total \\
\hline Maximum flow (frames/s) & 48 & 49 & 4 & 2 & 103 \\
\hline Average flow (frames/s) & 36 & 36 & 0 & 0 & 72 \\
\hline Total frames transferred & 3240 & 3247 & 33 & 27 & 6547 \\
\hline Maximum transfer rate & $50.30 \mathrm{~KB} / \mathrm{s}$ & $7.64 \mathrm{~KB} / \mathrm{s}$ & $308 \mathrm{~B} / \mathrm{s}$ & $184 \mathrm{~B} / \mathrm{s}$ & $58.42 \mathrm{~KB} / \mathrm{s}$ \\
\hline - Average transfer rate & $47.54 \mathrm{~KB} / \mathrm{s}$ & $4.25 \mathrm{~KB} / \mathrm{s}$ & $51 \mathrm{~B} / \mathrm{s}$ & $39 \mathrm{~B} / \mathrm{s}$ & $51.87 \mathrm{~KB} / \mathrm{s}$ \\
\hline Total data transferred & 4.14MB & $336.88 \mathrm{~KB}$ & $2.63 \mathrm{~KB}$ & $2.41 \mathrm{~KB}$ & $4.48 \mathrm{MB}$ \\
\hline \multicolumn{6}{|c|}{ SCTP } \\
\hline & Incoming & Outgoing & Through & Broadcast & Total \\
\hline Maximum flow (frames/s) & 71 & 74 & 11 & 3 & 159 \\
\hline Average flow (frames/s) & 36 & 35 & 0 & 0 & 71 \\
\hline Total frames transferred & 3537 & 3450 & 31 & 31 & 7049 \\
\hline Maximum transfer rate & $51.69 \mathrm{~KB} / \mathrm{s}$ & $23.84 \mathrm{~KB} / \mathrm{s}$ & $851 \mathrm{~B} / \mathrm{s}$ & $276 \mathrm{~B} / \mathrm{s}$ & $76.62 \mathrm{~KB} / \mathrm{s}$ \\
\hline Average transfer rate & $46.43 \mathrm{~KB} / \mathrm{s}$ & $3.76 \mathrm{~KB} / \mathrm{s}$ & $8 \mathrm{~B} / \mathrm{s}$ & $21 \mathrm{~B} / \mathrm{s}$ & $50.22 \mathrm{~KB} / \mathrm{s}$ \\
\hline Total data transferred & 4.15 MB & $447.26 \mathrm{~KB}$ & $2.14 \mathrm{~KB}$ & $2.67 \mathrm{~KB}$ & $4.59 \mathrm{MB}$ \\
\hline
\end{tabular}

Tabel 3. Hasil Pengujian TCP

\begin{tabular}{|c|c|c|c|c|c|c|c|}
\hline \multirow[t]{2}{*}{ No } & \multirow[t]{2}{*}{ Laptop } & \multirow[t]{2}{*}{ Waktu } & \multicolumn{5}{|c|}{ TCP } \\
\hline & & & Incoming & Outgoing & Trough & Broadcast & Total \\
\hline \multirow[t]{3}{*}{1} & \multirow{3}{*}{\begin{tabular}{|l} 
Laptop \\
(wireless)
\end{tabular}} & 22.00 & $4.15 \mathrm{MB}$ & $399.29 \mathrm{~KB}$ & $2.08 \mathrm{~KB}$ & $2.63 \mathrm{~KB}$ & $4.54 \mathrm{MB}$ \\
\hline & & 06.30 & $4.14 \mathrm{MB}$ & $376.33 \mathrm{~KB}$ & $2.01 \mathrm{~KB}$ & $2.23 \mathrm{~KB}$ & $4.52 \mathrm{MB}$ \\
\hline & & 13.30 & $4.03 \mathrm{MB}$ & $599.54 \mathrm{~KB}$ & $1.02 \mathrm{~KB}$ & $1.61 \mathrm{~KB}$ & $4.14 \mathrm{MB}$ \\
\hline \multirow[t]{3}{*}{2} & \multirow{3}{*}{$\begin{array}{l}\text { Laptop } \\
\text { (LAN) }\end{array}$} & 22.00 & $4.14 \mathrm{MB}$ & $388.36 \mathrm{~KB}$ & $2.08 \mathrm{~KB}$ & $2.66 \mathrm{~KB}$ & $4.53 \mathrm{MB}$ \\
\hline & & 06.30 & $4.16 \mathrm{MB}$ & $352.07 \mathrm{~KB}$ & $2.01 \mathrm{~KB}$ & $2.24 \mathrm{~KB}$ & $4.42 \mathrm{MB}$ \\
\hline & & 13.30 & $4.01 \mathrm{MB}$ & $601.95 \mathrm{~KB}$ & $1.02 \mathrm{~KB}$ & $1.77 \mathrm{~KB}$ & $4.08 \mathrm{MB}$ \\
\hline \multirow[t]{3}{*}{3} & \multirow{3}{*}{$\begin{array}{l}\text { PC } \\
(10 \text { Meter })\end{array}$} & 22.00 & $5.34 \mathrm{MB}$ & $87.70 \mathrm{~KB}$ & $51.52 \mathrm{~KB}$ & $4.95 \mathrm{~KB}$ & $5.48 \mathrm{MB}$ \\
\hline & & 06.30 & $5.34 \mathrm{MB}$ & $87.70 \mathrm{~KB}$ & $51.52 \mathrm{~KB}$ & $4.95 \mathrm{~KB}$ & $5.48 \mathrm{MB}$ \\
\hline & & 13.30 & $5.33 \mathrm{MB}$ & $87.89 \mathrm{~KB}$ & $51.52 \mathrm{~KB}$ & $4.95 \mathrm{~KB}$ & $5.47 \mathrm{MB}$ \\
\hline \multirow[t]{3}{*}{4} & \multirow{3}{*}{$\begin{array}{l}\mathrm{PC} \\
(25 \text { Meter })\end{array}$} & 22.00 & $5.34 \mathrm{MB}$ & $87.70 \mathrm{~KB}$ & $51.22 \mathrm{~KB}$ & $4.95 \mathrm{~KB}$ & $5.48 \mathrm{MB}$ \\
\hline & & 06.30 & $5.34 \mathrm{MB}$ & $87.70 \mathrm{~KB}$ & $51.31 \mathrm{~KB}$ & $4.95 \mathrm{~KB}$ & $5.48 \mathrm{MB}$ \\
\hline & & 13.30 & $5.34 \mathrm{MB}$ & $87.70 \mathrm{~KB}$ & $51.07 \mathrm{~KB}$ & $4.95 \mathrm{~KB}$ & $5.48 \mathrm{MB}$ \\
\hline
\end{tabular}


Tabel 4. Hasil Pengujian UDP

\begin{tabular}{|c|c|c|c|c|c|c|c|}
\hline \multirow[t]{2}{*}{ No } & \multirow[t]{2}{*}{ Laptop } & \multirow[t]{2}{*}{ Waktu } & \multicolumn{5}{|c|}{ UDP } \\
\hline & & & Incoming & Outgoing & Trough & Broadcast & Total \\
\hline \multirow[t]{3}{*}{1} & \multirow{3}{*}{$\begin{array}{l}\text { Laptop } \\
\text { (wireless) }\end{array}$} & 22.00 & $4.14 \mathrm{MB}$ & $336.88 \mathrm{~KB}$ & $2.63 \mathrm{~KB}$ & $2.41 \mathrm{~KB}$ & $4.48 \mathrm{MB}$ \\
\hline & & 06.30 & $4.04 \mathrm{MB}$ & $356.73 \mathrm{~KB}$ & $2.72 \mathrm{~KB}$ & $2.56 \mathrm{~KB}$ & $4.49 \mathrm{MB}$ \\
\hline & & \begin{tabular}{|l|}
13.30 \\
\end{tabular} & $3.86 \mathrm{MB}$ & $836.67 \mathrm{~KB}$ & $1.96 \mathrm{~KB}$ & $0.43 \mathrm{~KB}$ & $4.40 \mathrm{MB}$ \\
\hline \multirow[t]{3}{*}{2} & \multirow{3}{*}{$\begin{array}{l}\text { Laptop } \\
\text { (LAN) }\end{array}$} & 22.00 & $4.16 \mathrm{MB}$ & $338.45 \mathrm{~KB}$ & $2.64 \mathrm{~KB}$ & $2.42 \mathrm{~KB}$ & $4.47 \mathrm{MB}$ \\
\hline & & 06.30 & $4.10 \mathrm{MB}$ & $356.39 \mathrm{~KB}$ & $2.61 \mathrm{~KB}$ & $2.59 \mathrm{~KB}$ & $4.48 \mathrm{MB}$ \\
\hline & & 13.30 & $3.91 \mathrm{MB}$ & $836.07 \mathrm{~KB}$ & $1.74 \mathrm{~KB}$ & $0.47 \mathrm{~KB}$ & $4.37 \mathrm{MB}$ \\
\hline \multirow[t]{3}{*}{3} & \multirow{3}{*}{$\begin{array}{l}\text { PC } \\
\text { (10 Meter) }\end{array}$} & 22.00 & $5.43 \mathrm{MB}$ & $119.63 \mathrm{~KB}$ & $36.73 \mathrm{~KB}$ & $5.63 \mathrm{~KB}$ & $5.58 \mathrm{MB}$ \\
\hline & & 06.30 & $5.43 \mathrm{MB}$ & $119.63 \mathrm{~KB}$ & $36.73 \mathrm{~KB}$ & $5.63 \mathrm{~KB}$ & $5.58 \mathrm{MB}$ \\
\hline & & 13.30 & $5.42 \mathrm{MB}$ & $127.63 \mathrm{~KB}$ & $36.73 \mathrm{~KB}$ & $5.61 \mathrm{~KB}$ & $5.58 \mathrm{MB}$ \\
\hline \multirow[t]{3}{*}{4} & \multirow{3}{*}{$\begin{array}{l}\text { PC } \\
(25 \text { Meter })\end{array}$} & 22.00 & $5.43 \mathrm{MB}$ & $119.63 \mathrm{~KB}$ & $36.73 \mathrm{~KB}$ & $5.63 \mathrm{~KB}$ & $5.58 \mathrm{MB}$ \\
\hline & & \begin{tabular}{|l|}
06.30 \\
\end{tabular} & $5.43 \mathrm{MB}$ & $119.63 \mathrm{~KB}$ & $36.73 \mathrm{~KB}$ & $5.63 \mathrm{~KB}$ & $5.58 \mathrm{MB}$ \\
\hline & & 13.30 & $5.43 \mathrm{MB}$ & $127.63 \mathrm{~KB}$ & $36.29 \mathrm{~KB}$ & $5.63 \mathrm{~KB}$ & $5.58 \mathrm{MB}$ \\
\hline
\end{tabular}

Tabel 5. Hasil Pengujian SCTP

\begin{tabular}{|c|c|c|c|c|c|c|c|}
\hline \multirow[t]{2}{*}{ No } & \multirow[t]{2}{*}{ Laptop } & \multirow[t]{2}{*}{ Waktu } & \multicolumn{5}{|c|}{ SCTP } \\
\hline & & & Incoming & Outgoing & Trough & Broadcast & Total \\
\hline \multirow[t]{3}{*}{1} & \multirow{3}{*}{$\begin{array}{l}\text { Laptop } \\
\text { (wireless) }\end{array}$} & 22.00 & $4.15 \mathrm{MB}$ & $447.26 \mathrm{~KB}$ & $2.14 \mathrm{~KB}$ & $2.67 \mathrm{~KB}$ & $4.59 \mathrm{MB}$ \\
\hline & & 06.30 & $4.16 \mathrm{MB}$ & $467.65 \mathrm{~KB}$ & $2.24 \mathrm{~KB}$ & $2.87 \mathrm{~KB}$ & $4.60 \mathrm{MB}$ \\
\hline & & 13.30 & $4.12 \mathrm{MB}$ & $475.34 \mathrm{~KB}$ & $2.19 \mathrm{~KB}$ & $2.19 \mathrm{~KB}$ & $4.58 \mathrm{MB}$ \\
\hline \multirow[t]{3}{*}{2} & \multirow{3}{*}{$\begin{array}{l}\text { Laptop } \\
\text { (LAN) }\end{array}$} & 22.00 & $4.16 \mathrm{MB}$ & $447.86 \mathrm{~KB}$ & $2.15 \mathrm{~KB}$ & $2.71 \mathrm{~KB}$ & $4.58 \mathrm{MB}$ \\
\hline & & 06.30 & $4.14 \mathrm{MB}$ & $467.97 \mathrm{~KB}$ & $2.27 \mathrm{~KB}$ & $2.79 \mathrm{~KB}$ & $4.57 \mathrm{MB}$ \\
\hline & & 13.30 & $4.01 \mathrm{MB}$ & $475.66 \mathrm{~KB}$ & $2.11 \mathrm{~KB}$ & $2.09 \mathrm{~KB}$ & $4.58 \mathrm{MB}$ \\
\hline \multirow[t]{3}{*}{3} & \multirow{3}{*}{$\begin{array}{l}\text { PC } \\
\text { (10 Meter) }\end{array}$} & 22.00 & $5.43 \mathrm{MB}$ & $137.84 \mathrm{~KB}$ & $36.32 \mathrm{~KB}$ & $12.47 \mathrm{~KB}$ & $5.61 \mathrm{MB}$ \\
\hline & & 06.30 & $5.43 \mathrm{MB}$ & $137.84 \mathrm{~KB}$ & $36.32 \mathrm{~KB}$ & $12.47 \mathrm{~KB}$ & $5.61 \mathrm{MB}$ \\
\hline & & 13.30 & $5.43 \mathrm{MB}$ & $137.84 \mathrm{~KB}$ & $36.32 \mathrm{~KB}$ & $12.47 \mathrm{~KB}$ & $5.61 \mathrm{MB}$ \\
\hline \multirow[t]{3}{*}{4} & \multirow{3}{*}{$\begin{array}{l}\mathrm{PC} \\
(25 \text { Meter })\end{array}$} & 22.00 & $5.43 \mathrm{MB}$ & $137.84 \mathrm{~KB}$ & $36.32 \mathrm{~KB}$ & $12.47 \mathrm{~KB}$ & $5.61 \mathrm{MB}$ \\
\hline & & 06.30 & $5.43 \mathrm{MB}$ & $137.84 \mathrm{~KB}$ & $36.32 \mathrm{~KB}$ & $12.45 \mathrm{~KB}$ & $5.61 \mathrm{MB}$ \\
\hline & & 13.30 & $5.43 \mathrm{MB}$ & $137.84 \mathrm{~KB}$ & $36.31 \mathrm{~KB}$ & $12.39 \mathrm{~KB}$ & $5.61 \mathrm{MB}$ \\
\hline
\end{tabular}

Hasil pengujian menunjukkan bahwa protocol SCTP adalah protocol yang paling bagus untuk aktivitas multimedia ditandai dengan besarnya jumlah frame dan data yang berhasil ditansfer. sehingga akan menghasilkan kualitas video yang bagus (Tidak putus-putus dan lain sebagainya).

\section{KESIMPULAN}

Dari serangkain penelitian yang dilakukan, dapat disimpulkan hal-hal sebagai berikut.

1. Protokol SCTP lebih bagus untuk lalu lintas multimedia ditandai dengan besar frame yang berhasil ditansper. Karena se- perti kita ketahui multimedia merupakan pengabungan dari pada beberapa buah frame dan audio. Dengan semakin besarnya frame yang berhasil ditansper menandakan frame yang gagal ditansper semakin sedikit sehingga akan menghasilkan video (multimedia) yang baik.

2. Protocol SCTP tidak baik digunakan untuk aktivitas sehari-hari dikarenakan protocol ini akan menggunakan kemampuan dari media untuk melakukan transper (Troughtput) yang besar sehingga hanya kita bisa melakukan aktivitas satu persatu.

3. Protokol TCP merupakan protocol yang paling stabil dan bisa digunakan untuk 
aktivitas secara bersamaan seperti memutar video streaming, sambil browsing dan lain-lain.

4. Untuk tampilan Softperfect Protocol Analyzer memiliki tampilan yang mudah dipahami serta mudah di gunakan.

\section{DAFTAR PUSTAKA}

Anwar Prabu Mangkunegara, 2005. Sumber Daya Manusia perusahaan. Remaja Rosda karya: Bandung

Dhida, 2003. Monitoring Jaringan Komputer dengan Network Protokol Analyzer. Komunikas Elearning IlmuKomputer.com

Sutalaksana, Iftikar, dkk, 1979. Teknik Tata Cara Kerja, Departemen Teknik Industri - ITB, Bandung.

Syafrizal, Melwin. 2005. Pengantar Jaringan Komputer. ANDI, Yogyakarta.

Sofana, Iwan. 2008. Membangun Jaringan Komputer. Informatika. Bandung.

Tanenbaum, A. S. 2003. Computer Networks, Fourth Edition. Prentice-Hall International,Inc.

Kurose, J.F. dan Ross, K.W. 2003. Computer Networking A top down approach Featuring the Internet. Second Edition. Pearson Education, USA

Suyanto, M. 2004 Aplikasi Desain Grafis untuk Periklanan, Andi Offset. Yogyakarta 